\title{
An Overview of Problem Solving Studies in Physics Education
}

\author{
Elif Ince ${ }^{1}$ \\ ${ }^{1}$ Istanbul University Hasan Ali Yucel Education Faculty Science Education, Istanbul, Turkey \\ Correspondence: Assoc. Prof. Dr. Elif INCE, Istanbul University Hasan Ali Yucel Education Faculty Science \\ Education, Istanbul, Turkey.
}

Received: April 20, 2018

Accepted: May 10, 2018 Online Published: May 15, 2018

doi:10.5539/jel.v7n4p191

URL: https://doi.org/10.5539/jel.v7n4p191

\begin{abstract}
Education policies today aim to raise individuals with 21 st Century skills considered as a universal necessity and problem-solving skill is the one of the skills that have emerged as a requirement of the 21 st century. Teaching problem solving is one of the most important topics of physics education, it is also the field where students have the most problems. While trying to solve physics problems, students often express that they understand the questions, they know the laws of physics on which the problem is based they have solved many similar problems, but the new problem is different from the previous problems therefore they cannot solve the problem. The aim of this study is to present an overview problem solving studies in physics education according to student level, methodology, and development of the problem-solving strategies usage chronologicaly.
\end{abstract}

Keywords: physics education, problem solving, physics problem solving, physics problem solving studies

\section{Introduction}

At every stage of our lives, we encounter various problems, which can sometimes be difficult, and we strive to solve these problems. While trying to solve these problems, either we apply strategies that we used to solve similar problems before or use different approaches.

Many different definitions of the concept of problem have been made by researchers. Problem is defined by many researches as "a situation which people suddenly encounter and do not know how to react at the moment" (Reys et al.,, 1998), "anything that can make people's beliefs and opinions unclear" (Korsunsky, 2003), "any situation that creates ambiguity, curiosity and doubt" (Charles and Lester, 1982), "situations which create a desire to solve in people and which people are not ready to solve but they can solve using their previous experience or knowledge when they encounter" (Blum and Niss, 1991). When all these definitions are examined, it can be argued that a problem is a difficulty, which individuals need to, remove but that do not have a preparation regarding the solution. Therefore, a problem is a situation, which requires effort and the use of available knowledge and experience. It is possible to classify problems according to different criteria; but it is not possible to distinguish the classes from each other with certain lines; they can have overlapping properties.

Problem solving is defined as a person's ability to cope with a problem. It is also defined as "the process required overcoming the difference between the desired situation and the current situation in a situation affected by variables which were encountered or were not encountered previously" (Huitt, 1992). Additionally, problem solving requires people to construct knowledge to cope with difficulties and may require the use of some strategies to remove undesirable situations. Problem solving process, also defined as organizing cognitive and effective behavioral processes towards a specific target, is closely related to creativity.

The concept of "problem" has been classified into various categories in the literature such as Routine and Non-routine Problems, Everyday Problems and Intellectual Problems, Well Structured and Not-Well Structured Problems, Complex Problems, Problems with a Single Correct Answer and Multidimensional Problems, Problems that Require A Little Prior Knowledge, Problems that Require Much Prior Field-Based Knowledge, Problems that Require Additional Information, Problems with Multiple Uncertainties, Problems whose Similars were Previously Experienced and Problems that Can Be Solved with a Single Step. It is possible to classify problems according to different criteria; but it is not possible to distinguish the classes from each other with certain lines; they can have overlapping properties (Polya, 1997; Osborne \& Gilbert, 1980; Jonassen, 2000; Hitz, 1992; Simon, 1975; Adair, 2000).

When the literature is examined, scientists in agree that problem solving process is an activity that requires field 
knowledge and appropriate cognitive strategies and argue that it is necessary to use a systematic method to solve problems. Many methods have been developed to make this systematic. These methods, created using common properties, also lead to success in problem solving. Some of these problem-solving methods are divergent thinking, convergent thinking, brainstorming, lateral thinking, expanding or narrowing thinking, associating, comparing, combining, and utilizing objects and concepts.

The basic steps of problem-solving phases include many basic thinking processes such as individual's becoming aware of and understanding a known or defined problem, collecting information needed to overcome this problem, searching for solutions, testing the suitability of these solutions, choosing the most suitable solution and assessment of the solution of the problem.

\section{Studies on Problem Solving in Physics Education}

The aim of this study is to present an overview problem solving studies in Physics Education. For this purpose, the results of the extensive research dating back to 1980's have been presented chronologically. In addition, student level, methodology used for the studies were also presented. Studies of the same authors involving similar results or studies with small sample groups have not been reported in this section. Most of the studies involved are experimental studies with pre-posttest control groups, which is quite important to observe the effectiveness of problem-solving strategies when used as a method.

In the study published by Jong and Hessler in 1986, students with high and low success in solving physics problems investigated ways to organize knowledge for problem solving. The study argued that the students with high problem-solving achievement in physics are more successful in organizing knowledge than those who have fewer problems solving achievement, that they used more and various methods. In addition, the study suggested that computational error, affective and motivational factors are influential in problem solving achievement in physics (Jong and Hessler, 1986).

In 1988, Hardiman et al., studied the problem-solving processes of expert and novice problem solvers. The study was conducted with 45 university physics students and 8 physics doctoral students. The study results revealed that expert problem solvers have an in-depth analysis, decision-making mechanism, and they act based on analysis according to principles whereas novice problem solvers generally have a superficial approach (Hardiman et al., 1988).

In a study published by Jong and Hessler in 1991, university students' problem-solving abilities in physics were examined in terms of their problem-solving success in physics. For this purpose, they identified 12 students with low success and 11 with high success and examined students' problem-solving processes in terms of their ability to reconfigure the problem and to establish operational and conceptual information links. This study demonstrated that the students that are successful in problem solving are better in reconfiguring the problem than those who are less successful in problem solving and that the students with low achievement in problem solving have a superficial approach towards the problem while the ones with high achievement establish operational and conceptual information links correctly (Jong and Hessler, 1991).

Heller et al. (1992) investigated how the problem-solving performances of high school students differed after they used problem solving strategy in cooperative groups in physics classes. In this study, which used contextually rich problems, a 5-step problem solving strategy was used. 91 students who had previously practiced problem solving in collaborative groups realized problem solving practice on their own while 118 students implemented this practice in cooperative groups. In this study, which used a 6-step problem solving strategy scoring rubric as a measurement tool, the difficulty ratings of problems were evaluated in 6 stages. This study revealed that the students who were in the experimental group and who used problem solving strategy in cooperative groups showed higher performances of problem solving. In addition to this, it was stated that contextually rich problems improved the conceptual learning of students (Heller et al., 1992).

Heller and Hallabaugh (1992) aimed to invesitagate of students' physics problem-solving strategies in collaborative groups. In this study carried out with 400 university students, they used contextually rich university level physics problems. According to the results of this study, students in collaborative groups used problem solving strategies more effectively and the type of problem is also important in the implementation of problem solving strategies (Heller and Hallabaugh, 1992).

In his study published in 1993 based on literature review, Harmon investigated the best behaviors for an effective problem solving and analyzed researches on expert and novice problem-solving behaviors and studies on problem solving success. He finally reported that the teaching of cognitive awareness strategies is required to be a good problem solver (Harmon, 1993). 
In a study published in 1997 by Dufrense et al., a different method was applied to students in the use of problem-solving strategies. In the study carried out with 376 university students, the strategies that were required to be used by the experimental group students in the solution of the physics problems were presented by the teacher and the students were asked to write these strategies. Thus, a common language for problem solving was developed. In the study, the final exam grades were used as the assessment and evaluation. The exams revealed that two-thirds of the students in the experimental group had the ability to write adequate strategies for the solution and they performed more successfully than the control group students in terms of which concepts and principles were required for the problems (Dufrense et al., 1997)

In 1997, Huffman explored the impacts of the explicit problem-solving strategy on the conceptual perceptions of high school students. In the study, which was carried out semi-experimentally with 145 students, the problem-solving strategies were taught to the students in the experimental group while solutions to the problems in the textbooks were presented to the students in the control group. According to this study using force concept test and problem-solving strategy rubric as a measurement tool, the students in the experimental group made progress in the visualization step of problem solving strategies. However, in the steps of establishing equality, using formulas, mathematical processing skills, there was no difference in the ability of using use problem solving strategies of the experimental and control group students (Huffman, 1997).

The study, published by Netto and Valente in 1997, examined the effect of students' using cognitive awareness strategies in solving physics problems. In this semi-experimental study, problem solving skills of secondary school students were investigated according to the problem-solving steps including cognitive awareness strategies. The study results reported that the students who applied cognitive awareness strategies in problem solving steps were better at problem solving (Netto and Valente, 1997).

Bagno and Eylon (1997) studied the problem solving, conceptual understanding and structuring of knowledge in solving high school physics problems on electromagnetism. In this study, which was conducted experimentally with 180 students, explanations were made to the experiment group students about the correctness of solution and how the students structured concepts were researched using concept maps. According to the results of this study, the students in the experimental group performed better than the students in the control group in problem solving and conceptual understanding. They were also better at transferring new knowledge to different fields (Bagno and Eylon, 1997).

Dhillon (1997) investigated the differences in problem solving behaviors of expert and novice problem solvers. The study included 1 teaching staff at a university's physics department, 2 physics department doctoral students, 4 physics department graduate students, 6 university first grade physics students. 14 of the participants were asked to think aloud while solving physics problems. Written test was used, and the entire process was recorded in the study. All participants were interviewed after the application. "Visualization", one of the steps of problem solving strategy, was the distinguishing feature of expert and novice problem solvers in this study. According to the results of the study, the novice problem solvers focused primarily on solving the problem while the expert problem solvers tried to visualize the problem and use the problem-solving strategies (Dhillon, 1997).

In their work published in 2001, Heller et al. studied the beliefs of teaching staff and students in the physics departments of universities regarding teaching and learning problem solving. The data they gathered through the interviews showed that the teaching staff thought that some of the students believed that problem solving is a linear process but that problem solving requires self-monitoring and evaluation throughout the process (Heller et al., 2001).

In a study published by Sherin in 2001, it was investigated how university students perceived equations in physics problems. In the study conducted with a total of 10 students in groups of two, Sherin reported that students produced equations far from the scientific reality and the use of mathematical expressions was incomplete (Sherin, 2001).

In 2001, Zou explored the impact of using graphics in the work-energy subject on problem solving skills of students. In the study conducted with 3 physics problem solutions and interviews, he reported that with the use of graphics, students could better understand the concepts on which the problem was based, set up equations more accurately, and better evaluate the solution of the problem (Zou, 2001).

Hsu et al. examined 109 studies in the literature review on the problem solving published in 2004. These studies were reported that computer-based problem-solving approaches, application of problem solving steps, use of concept maps in problem solving, cooperative problem-solving method were conducted in previous literature. It was also emphasized that these studies were on the use of problem solving steps as a method and putting forward a solution method depending on a certain concept in physics (Hsu et al., 2004). 
In 2005, Kohl and Finkelstein investigated the effects of mathematical, pictorial, graphical and expressive presentations on problem solving skills of students in physics problems. In this work, which was carried out semi-experimentally with homework including these 4 dimensions which are mathematical, pictorial, graphical and expressive, it was reported that students can more easily solve the problems indicated by pictorial expressions (Kohl and Finkelstein, 2005).

In a study published by De Leone and Gire in 2005, the impact of non-mathematical presentation on students' problem-solving success in physics was investigated. In the study conducted with 39 university students, the students who solved the given physics problems using mathematical expressions and those who solved using only presentations without mathematical expressions were evaluated. This study argued that the students who did not utilize mathematical expressions were successful. It was also stated in the study that the students with inadequate mathematical knowledge need to solve physics problems through this method (De Leone and Gire, 2005).

In 2006, Meijer et al. presented taxonomy of cognitive awareness activities developed for secondary school students to solve physics problems. This taxonomy consists of four main steps as orientation, planning, evaluation, elaboration, and some specific behaviors accompanying these steps (Meijer et al., 2006).

In the study published by Kohl et al. in 2006, students' using multiple representations in solving physics problems was examined. The study was conducted by interviewing 6 students. In the first phase of the study, the first semester physics topics were taught to the students through problem solving practice using free body diagrams, graphs, words and mathematical equations. 2 people with the highest score, 2 people with the lowest score and 2 people with the medium score from this application were selected as samples. Later, when the students were solving the physics problems given to them, they were also interviewed. The study results indicated that all the students had difficulties while applying the methods they had learned during the first semester, and that the performances of the most successful students were different and more appropriate than the other students (Kohl et al., 2006).

Çalışkan et al. (2006) investigated what kind of strategies the students in the department of physics teaching used while solving physics problems and what problem-solving behaviors they showed in this process. The study revealed that the use of problem solving strategies of preservice teachers at 1st, 2nd and 3rd grades adopted a superficial approach to problem solving whereas those at the 4th grade had a deeper approach and used more problem-solving strategies (Çalışkan et al., 2006).

The study published by Gök in 2006 investigated the effects of cooperative problem-solving strategies teaching method on high school students' physics success, achievement motivation, and problem-solving attitude, strategy use, and gender and achievement levels. In the experimental study, it was reported that teaching cooperative problem-solving strategies had positive effects on students' achievement, attitude and achievement of physics (Gök, 2006).

Malone's research published in 2008, he investigated the effects of cognitive awareness strategies in problem-solving skills of high school students in physics classes. In this semi-experimental study, the students in the experimental group were applied the cognitive awareness skills whereas the students in the control group were applied traditional teaching method. The study results indicated that cognitive awareness skills of the students in the group to which the method of problem solving skills was applied were high and these students were defined as expert problem solvers. On the other hand, the problem-solving abilities of the students who were applied traditional teaching methods were low and these students showed similar characteristics to novice problem solvers (Malone, 2008).

In his study published in 2008, Çalışkan et al examined the effects of teaching problem solving strategies on the achievement, attitudes, self-efficacy, and strategy using skills, and problem-solving performances of first year university students in physics course. The research results indicated that problem solving strategies teaching had positive effects on physics achievement, attitude toward physics, physics self-efficiency and physics problems solving (Çalışkan et al., 2008).

In the study published by Selçuk et al in 2008, the effects of problem solving strategy used in university physics courses on students' physics success, problem solving performances and ability to use problem solving strategies were investigated. In this study, which was conducted semi - experimentally with 74 students, physics achievement test, problem solving performance test and the measurement test of problem - solving strategies prepared according to Polya's problem solving strategies were used. Physics achievements, problem solving performances and problem-solving skills of the students were found to be high at significant levels in this study (Selçuk et al., 2008). 
The study published by Gök and Silay in 2008, they investigated the effects of gender factor in cooperative learning groups on high school students' physics achievement and using problem solving strategies. In this experimental study, physics achievement test, problem solving strategies scale and problem-solving sheets were used as the measurement tools. In the study results, it was reported that the gender variable did not influence the students' physics achievement and problem-solving strategies (Gök and Silay, 2008).

Çalışkan et al. (2010) investigated the effects of problem-solving strategy teaching on students' ability to solve physics problems and to use physics problem solving strategy. In this semi-experimental study conducted with 77 university students, physics achievement grades and the problem-solving strategy usage rubric developed by the researchers were used as the measurement tools. The study results indicated that problem solving strategy teaching increased both problem solving performances and problem-solving strategy using skills of the students (Çalışkan et al., 2010).

Özcan's research published in 2011 investigated the problem-solving approaches of preservice physics teachers towards solving the problems of special relativity theory. In this study conducted with 34 students at university, 2 problems and semi-structured interview questions were used to determine students' problem-solving approaches. The study results indicated that the problem-solving behaviors of most of the preservice teachers were not scientific or did not include strategic solution approaches (Özcan, 2011).

Yiğit et al.'s study published in 2012 investigated the ability of science students to read the problems in physics classes and accurately convey the desired results on paper. This study, using a screening model, was conducted with 40 students. For this purpose, 5 open-ended questions were used, and the answers were classified according to the students' ability to convert the texts to shapes and define shape-supported texts on a shape. The study results demonstrated that the students were not able to explain what was described and what they were asked in the questions presented in texts and shapes (Yiğit et al., 2012).

In 2012, Abubakar and Danjuma explored the impacts of explicit problem-solving strategy (focusing on the problem, defining the problem, planning for solution, implementation of the plan, and evaluation of solution) on students' academic achievement and remembrance. They used a quartet Solomon model in this study, which they conducted with 80 high school students. As a means of measurement, the physics achievement test developed by the researchers themselves was used. According to the results of the three-dimensional variance analysis, this strategy is the best strategy to improve the academic achievement of the students in high school physics classes and to enable them to remember the past knowledge (Abubakar and Danjuma, 2012).

Taasoobshirazi and Ferley's study published in 2013 investigated the relationships among expert problem solvers' motivations, ability to use metacognition strategies, ability to categorize problems, and ability to use free body diagrams while solving physics problems. In this study conducted with 121 university students, physics motivation test, metacognitive self-regulation test and 5 open-ended well-structured physics problems were used as the measurement tools. According to the results of the study, explained by the structural equation model, the strategy uses of the motivation variable influences metacognitive planning and problem categorization, and the strategy using skill and problem categorization increase the ability of problem solving (Taasoobshirazi and Ferley, 2013).

In a study published by Maries and Singh in 2013, the ability of university students to draw diagrams while solving physics problems was investigated. In this study conducted with 118 university students, 2 problems were asked to the students. The problems were prepared in a structure that can be solved both by drawing a diagram and by using mathematical equations. In this study, it was determined that students did not prefer to draw diagrams while solving problems (Maries and Singh, 2013).

Marlina et al (2014) investigated how students' success in physics problems could be determined. In the study conducted with 21 university students, students were asked to solve 4 physics problems in a written test and to think aloud while solving. This process was recorded, and interviews were held with the students after the implementation. According to the results of this study, students who can use metacognitive problem-solving strategy are successful and at the same time expert problem solvers (Marlina et al., 2014).

Byu and Lee (2014) investigated whether the students' self-confidence, academic achievement and conceptual understanding differed with the increase in the number of physics problems solved. In the study conducted with 49 high school students, force concept test and physics course achievement grades were used as measurement tools and interviews were made with 4 selected students. Students solved an average of 2200 physics problem. The results of this study revealed that the increase in the number of physics problems solved had no impacts on students' academic achievement, self-confidence and understanding of concepts and that students' performance of solving physics problems can be enhanced by the strategies learned and applied (Byu and Lee, 2014). 
In another work published in 2014, Gök explored the effects of using phased problem-solving strategies on students' achievement, problem solving skills, and self-confidence in problem solving. In this semi-experimental study carried out with 70 university students, physics achievement test, problem solving strategy steps scale, problem solving self-confidence test were used as the measurement tools. The study revealed that the use of phased problem-solving strategies increases students' physics achievement, problem solving skills in physics, and problem-solving self-confidence in physics (Gök, 2014).

In another study published by Gök in 2015, the effects of the problem-solving strategy realized through peer tutoring in the university physics courses on the students' physics achievement and problem-solving skills were investigated. In this study which was performed experimentally with 64 students, physics achievement test, problem solving strategies rubric and homework were used as measurement tools and interviews were made with the students after the application. The results of the study showed that the experimental group students' homework performance, achievement scores in physics and visualization, problem solving and solution control skills from problem solving strategies improved highly while there was no difference in the control group students' homework performance, achievement scores in physics and ability to apply problem solving strategies (Gök, 2015).

Körhasan and Özcan (2015) aimed to determine problem solving approaches of students by examining their use of mathematical models. In this study conducted with 92 university students, students were asked to give written answers in detail to the questions and semi-structured interviews were made with 6 students. In this study, it was pointed out that the ability of students to use mathematical model was low and they had difficulties in distinguishing some basic concepts (Körhasan and Özcan, 2015).

Olaniyan and Omosewo (2015) investigated the effects of Target-Task Problem Solving Model on students' problem-solving performances in physics. In this study, which was conducted semi-experimentally with 120 secondary school students, a test consisting of electrical problems was used as a measurement tool. In the study, it was reported that the Target-Task Problem Solving Model improves the performance of even the students with low performance (Olaniyan and Omosewo, 2015).

In a study published by Docktor el al. in 2015, it was investigated how high school physics teachers applied conceptual physics problem solving method. In the conceptual problem solving, teachers explained the concepts on which the problem was based and the relations between the concepts and prepared the techniques and plans that students would use. In this study, the teachers noted that this practice was easy to adapt to the curriculum and added that the students had improved their problem-solving skills and achievement grades through this method (Docktor el al., 2015).

In the study published by Alii et al in 2016, 21 university students were asked to think aloud while solving their physics problems and all data were recorded. Qualitative interviews were held with the students later. It was reported that the fact that the students thought aloud and knew that they were being watched while solving problems increased their success (Alii et al., 2016).

Halim et al. (2016) investigated the ability of students to apply problem solving strategies in physics. In the semi-experimental study carried out with 25 graduate students, routine problems were used, and rubrics were utilized as the measurement tool. Heller's "Troubleshooting Strategy" was used as the problem-solving strategy. According to the results of the study, it was determined that the students had difficulty in identifying the problem (Halim et al., 2016)

Reddy and Panacharoensawad (2017) evaluated the student's problem-solving skills and the factors influences the problem-solving difficulties in physics by 303 students of physics. In this study, it was indicated that poor mathematical skills and lacking understanding the problem are the major obstacles in the domain of problem solving skills in physics (Reddy and Panacharoensawad, 2017).

\section{Discussion and Conclusion}

The aim of this study is to present an overview problem solving studies in Physics Education. When the studies on problem solving in physics teaching are examined in the literature, it is observed that some of the studies are related to the factors affecting problem solving performance. These factors are reported as problem type, characteristics of problem solvers, their knowledge of the field, conceptual knowledge, whether they solved similar problems and metacognitive features.

As seen from the literature review, problem solving is considered as a goal, a method and a skill in some cases. If problem solving is used as a goal, then the problem must be well-structured and must involve everyday life problems. If problem solving is used as a method, then not only expert problem solvers but also all problem 
solvers need to develop their problem-solving skills. If problem solving is defined as a skill, it requires the use of a defined strategy and supports especially the development of expert problem solvers. While some of these studies aimed to determine students' problem-solving strategies, others revealed differences between expert and novice problem solvers. In general, after identifying the type of knowledge and problem-solving methods students have, a variety of problem-solving methods were developed to ensure the development of their problem-solving skills (Hardiman et al., 1988; Harmon, 1993; Dhillon, 1997; Malone, 2008; Reddy and Panacharoensawad, 2017).

Problem solving studies in the field of physics teaching have generally focused on problem solving behaviors according to those who are "experts and novices". The other field is the acquisition of problem-solving skills in the classroom and laboratory environment. According to this classification, those who can use problem-solving strategies efficiently and continuously are described as Expert Problem Solver, whereas those who cannot use these strategies adequately are defined as Novice Problem Solver. Studies have revealed that expert problem solvers first try to understand a problem by considering physics laws and formulas and then try to solve it through mathematical methods. Along with that, as problem solving strategies, they usually follow the steps of understanding the problem, determining the concepts, making the plan, solving the problem, and evaluation of the outcome. On the other hand, novice problem solvers try to solve problems by first using mathematical expressions. It was stated that a student's success in solving the physics problems depends not only on the student's knowing the concepts of physics but also on establishing relations between all the information and concepts in the problem. In this regard, it has been observed that expert problem solvers take more time to understand the problem and the concepts involved in the problem and to explore the relationship between these information and concepts whereas novice problem solvers cannot establish these connections, especially in complex and difficult problems.

In most of researches' results were presented related with determination of students' ability on general problem solving strategies sub-steps such as drawing diagrams, visualising, using mathematical equations and concept understanding (Jong and Hessler, 1991; Heller et al., 1992; Huffman, 1997; Bagno and Eylon, 1997; Zou, 2001; Sherin, 2001;Hsu et al., 2004; Meijer et al., 2006; Kohl et al., 2006; Maries and Singh, 2013; Taasoobshirazi and Ferley, 2013; Byu and Lee, 2014; Körhasan and Özcan, 2015). These studies show that the students' problem-solving skills are related to the performances of the problem solving sub-steps.

It has been pointed out that students' physics problem-solving abilities have affected the levels of metacognition, achievement, attitudes, motivation, self-efficacy and self-confidence (Jong and Hessler, 1986; Harmon, 1993; Netto and Valente, 1997; Gök, 2006; Çalışkan et al., 2008; Abubakar and Danjuma, 2012; Taasoobshirazi and Ferley, 2013; Byu and Lee, 2014; Gök, 2014; Docktor el al., 2015).

The research of this paper not only enriches the research literature but also has important significance for problem solving in physics education theory and practice; give a clear picture to understand the problem-solving strategies of educators for the preparation of future researches.

\section{References}

Abubakar, S. M., \& Danjuma, I. M. (2012). Effects of Explicit Problem-Solving Strategy on Students' Achievement and Retention Senior Secondary School Physics. Journal of Science, Technology \& Education, $1(1), 123-128$.

Adair, J. (2000). Karar Verme ve Problem Çözme (N. Kalaycı Çevr.). Ankara: Gazi Kitabevi.

Alii, M., Talib, C. A., Ibrahim, N. H., Surif, J., \& Abdullah, A. H. (2016). The Importance of Monitoring Skills in Physics Problem Solving. European Journal of Education Studies, 1(3), 1-10. https://doi.org/10.5281/zenodo.51089

Bagno, E., \& Eylon, Bat-S. (1997). From Problem Solving to a Knowledge Structure: An Example from the Domain of Electromagnetism. American Journal of Physics, 65, 726736. https://doi.org/10.1119/1.18642

Blum, W., \& Niss, M. (1991). Applied mathematical problem solving, modelling, applications, and links to subjects-state, trends and issues in mathematics instruction. Educational Studies in Mathematics, 22(1), $37-68$.

Byu, T., \& Lee, G. (2014). Why Students Still Can't Solve Physics Problems after Solving over 2000 Problems. American Journal of Physics, 82, 906-913. https://doi.org/10.1119/1.4881606

Çalışkan, S. (2007). Problem çözme stratejileri ögretiminin fizik başarısl, tutumu, özyeterliği üzerindeki etkileri ve strateji kullanımı. Yayınlanmamış Doktora Tezi, DEÜ, Eğitim Bilimleri Enstitüsü. 
Çalışkan, S., Selçuk, G. S. \& Erol M. (2006). Fizik Öğretmen Adaylarının Problem Çözme Davranışlarının Değerlendirilmesi. Hacettepe Üniversitesi Eğitim Fakültesi Dergisi, 30, 73-81.

Çalışkan, S., Selçuk, G., \& Erol, M. (2009). Instruction of Problem Solving Strategies: Effects on Physics Attitude. E-Journal of New World Sciences Academy, 4(2), $1 \mathrm{C} 0023$.

Çalışkan, S., Selçuk, G., \& Erol, M. (2010). Effects of the Problem-Solving Strategies Instruction on the Students' Physics Problem Solving Performances and Strategy Usage. Procedia Social and Behavioral Sciences, 2, 2239-2243. https://doi.org/10.1016/j.sbspro.2010.03.315

Charles, R. I., \& Lester, F. K., Jr. (1982). Teaching Problem Solving: What, Why, \& How. Palo Alto, CA: Seymour.

De Leone, C., \& Gire, E. (2005). Is Instructional Emphasis on the Use of Non-Mathemetical Representations Worth the Effort? Physics Education Research Conference, Salt Lake City, UT.

Dhillon, A. S. (1998). Individual Differences within Problem-Solving Strategies used in Physics. Science Education, $82(3)$, 279-405. https://doi.org/10.1002/(SICI)1098-237X(199806)82:3<379::AID-SCE5>3.0.CO;2-9

Docktor, J. L., Strand, N. L., Mestre, J. P., \& Ross, B. H. (2015). Conceptual Problem Solving in High School Physics. Physical Review Special Topics-Physics Education Research, 11, 1-13. https://doi.org/10.1103/PhysRevSTPER.11.020106

Dufrense, R., Gerace, W., \& Leonard, J. (1997). Solving Physics Problems with Multiple Representations. Physics Teacher, 35, 270-275. https://doi.org/10.1119/1.2344681

Gök, T. (2006). Fizik Öğretiminde İşbirlikli Öğrenme Gruplarında Problem Çözme Stratejilerinin Öğrenci Başarısı, Başarı Güdüsü ve Tutumu Üzerindeki Etkileri. Doktora Tezi, Dokuz Eylül Üniversitesi Eğitim Bilimleri Enstitüsü: İzmir.

Gök, T. (2014). Peer Instruction in the Physics Class Room: Effects on Gender Difference Performance, Conceptual Learning, and Problem Solving. Journal of Baltic Science Education, 13(6), 776-788.

Gök, T. (2015). An Investigation of Students' Performance after Peer Instruction with Stepwise Problem-Solving Strategies. International Journal of Science and Mathematics Education, 13(3), 562-582. https://doi.org/10.1007/s10763-014-9546-9

Gök, T., \& Sılay, İ. (2008). Fizik Eğitiminde İşbirlikli Gruplarda Problem Çözme Stratejilerinin Öğrenci Başarısı Üzerindeki Etkisi. Hacettepe Üniversitesi Eğitim Fakültesi Dergisi, 34, 116-126.

Halim, A., Yusrizal, Y., Susanna, S., \& Tarmizi, T. (2016). An Analysis of Students' Skill in Applying the Problem-Solving Strategy to the Physics Problem Settlement in Facing AEC as Global Competition. Journal Pendidikan IPA Indonesia, 5(1), 1-5.

Hardiman, P., Dufresne, R., \& Mestre, J. P. (1989). The relation between problem categorization and problem solving among experts and novices. Memory \& Cognition, 17(5), 627-638. https://doi.org/10.3758/BF03197085

Harmon, M. G. (1993). The Role of Strategies and Knowledge in Problem Solving: A Review of the Literature. Mississipi State University.

Heller, P., \& Hollabaugh, M. (1992). Teaching Problem Solving Through Cooperative Grouping. Part 2: Designing Problems and Structuring Groups. American Journal of Physics, 60, 637-644. https://doi.org/10.1119/1.17118

Heller, P., Heller, K., Henderson, C. R., Kuo, V., \& Yerushalmi, E. (2001). Instructors' Beliefs and Values about Learning Problem Solving. Part of the PER Conference Series, July 25-26, Rochester, New York. https://doi.org/10.1119/perc.2001.pr.005

Heller, P., Keith, R., \& Anderson, S. (1992). Teaching Problem Solving Through Cooperative Grouping. Part 1: Group versus Individual Problem Solving. American Journal of Physics, 60, 627-636. https://doi.org/10.1119/1.17117

Hsu, L., Brewe, E., Foster, T. M., \& Harper, K. A. (2004). Resource letter RPS-1: Research in problem solving. American Journal of Physics, 72(9), 1147-1156. https://doi.org/10.1119/1.1763175

Huffman, D. (1997). Effect of Explicit Problem-Solving Instruction on High School Students' Problem-Solving Performance and Conceptual Understanding of Physics. Journal of Research in Science Teaching, 34(6), 
551-570. https://doi.org/10.1002/(SICI)1098-2736(199708)34:6<551::AID-TEA2>3.0.CO;2-M

Huitt, W. (1992). Problem solving and decision making: Consideration of individual differences using the Myers-Briggs Type Indicator. Journal of Psychological Type, 24, 33-44.

Jonassen, D. H. (2000). Toward a Design Theory of Problem Solving. Educational Technology Research and Development, 48(4), 63-85. https://doi.org/10.1007/BF02300500

Jong, A. L. M., \& Hessler, M. G. M. (1986). Cognitive Structures of Good and Poor Novice Problem Solvers in Physics. Journal of Educational Psychology, 78(4), 179-288. https://doi.org/10.1037/0022-0663.78.4.279

Jong, A. L. M., \& Hessler, M. G. M. (1991). Knowledge of Problem Situations in Physics: A Comparison of Good and Poor Novice Problem Solvers. Learning and Instruction, 1(4), 289-302. https://doi.org/10.1016/0959-4752(91)90010-6

Kohl, P. B., \& Finkelstein, N. D. (2005). Representational Format, Student Choice, and Problem Solving in Physics. AIP Conference Proceedings, 790, 121. https://doi.org/10.1063/1.2084716

Kohl, P. B., Rosengrant, D., \& Finkelstein, N. D. (2006). Comparing Explicit and Implicit Teaching of Multiple Representation Use in Physics Problem Solving. Physics Education Research Conference, 883, 145-148. https://doi.org/10.1063/1.2508713

Körhasan, N. D., \& Özcan, Ö. (2015). Examination of the Variation in Students' Problem-Solving Approaches Due to the Use of Mathematical Models in Doppler Effect. Hacettepe University Journal of Education, 30(3), 87-101.

Korsunsky, B. (2003). Cognitive Mechanism of solving non-Trivial Physics Problems. Ph.D. Dissertation. Harvard University.

Maries, A., \& Singh, C. (2013). A Good Diagram is Valuable despite the Choice of a Mathematical Approach to Problem Solving. AIP Conference Proceedings, 1513, 31. https://doi.org/10.1119/perc.2013.inv.006

Marlina, A., Nor Hasniza, I., Abdul Halim, A., Johari, S., \& Nurshamela, S. (2014). Physics Problem Solving: Selecting More Successful and Less Successful Problem Solvers. International Conference of Teaching, Assessment and Learning, 186-191.

Meijer, J., Veenman, M. V. J., \& Hout-Wolters, B. H. A. M. (2006). Metacognitive Activities in Text-Studying and Problem-Solving: Development of a Taxonomy. Educational Research and Evaluation, 12(3), 209-237. http://dx.doi.org/10.1080/13803610500479991

Netto, A., \& Valente, M. O. (1997). Problem Solving in Physics: Towards A Metacognitively Developed Aproach. The Annual Meeting of the National Association for Research in Science Teaching. March 21-24, Oak Brook.

Olaniyan, O., \& Omosewo, E. O. (2015). Effects of a Target-Task Problem-Solving Model on Senior Secondary School Students' Performance in Physics. Science Education International, 25(4), 522-538.

Osborne, R. J., \& Gilbert, J. K. (1980). A Technique for Exploring Students' Views of the World. Physics Education, 15, 376-379. https://doi.org/10.1088/0031-9120/15/6/312

Özcan, Ö. (2011). Pre-Service Physics Teachers' Problem-Solving Approaches in Special Theory of Relativity. Hacettepe University Journal of Education, 40, 310-320.

Polya, G. (1997). Nasıl çözmeli? (Çeviri-F. Halatçı). İstanbul: Sistem Yayıncılık.

Reddy, M. V. B., \& Panacharoensawad, B. (2017). Students Problem-Solving Difficulties and Implications in Physics: An Empirical Study on Influencing Factors. Journal of Education and Practice, 8(14), 59-62.

Reys, R. E., Suydam, M. N., Lindquist, M. M., \& Smith, N. L. (1998). Helping Children Learn Mathematics (5th ed.). USA: Allyn and Bacon.

Selçuk, G. S., Çalışkan, S., \& Erol, M. (2008). The Effects of Problem Solving Instruction on Physics Achievement, Problem Solving Performance and Strategy Use. Latin American Journal of Physics Education, 2(3), 151-166.

Sherin, B. (2001). How Students Understand Physics Equations. Cognition and Instruction, 19(4), 479-541. http://dx.doi.org/10.1207/S1532690XCI1904_3

Simon, H. A. (1975). The Functional Equivalence of Problem Solving Skills. Cognitive Psychology, 7(2), 268-288. http://dx.doi.org/10.1016/0010-0285(75)90012-2 
Taasoobshirazi, G., \& Farley, J. (2013). A Multivariate Model of Physics Problem Solving. Learning and Individual Differences, 24, 53-62. https://doi.org/10.1016/j.lindif.2012.05.001

Yiğit, N., Alev, N., Tural, G., \& Bülbül, M. Ş. (2012). Fen Bilgisi I. Sınıf Öğretmen Adaylarının Elektrik Konusundaki Problemleri Anlama ve Çözme Durumları Üzerine Bir Araştırma. Cumhuriyet International Journal of Education, 1(2), 18-36.

Zou, X. (2001). The Role of Work-Energy Bar Charts as a Physical Representation in Problem Solving. Physics Education Research Conference, July 25-26, Rochester, New York. https://doi.org/10.1119/perc.2001.pr.021

\section{Copyrights}

Copyright for this article is retained by the author(s), with first publication rights granted to the journal.

This is an open-access article distributed under the terms and conditions of the Creative Commons Attribution license (http://creativecommons.org/licenses/by/4.0/). 